\title{
Jerusalem Trapped between the Vatican, Moscow, Republican Evangelism, Judaic Messianism, and Islam
}

\begin{abstract}
Jerusalem, especially the Temple Mount (Moriah), has been sanctified by the three biggest monotheistic religions. By Judaism - the binding of Isaac (Old Testament), King David pronouncing Jerusalem the capital of the ancient country of Israelites, and two demolished temples. By Christianity - Christ prayed in the Second Temple, and was later crucified and buried in Jerusalem. The ruins of the Second Temple became the site where the Muslim Al-Aqsa Mosque was built.

The contemporary conflict is marked by: the emergence of the State of Israel (1948) and the capturing of Jerusalem (1967), Russian influences exerted by the Orthodox Church and Oriental churches, the political impact of Jewish messianism combined with a mass support for evangelical fundamentalism as offered by the Republican Party in the US, the conflict between the West and Israel, focusing on Jerusalem as the tinderbox for "contemporary messiahs".
\end{abstract}

Keywords: fundamentalism, Jerusalem, conflict, Near East

1 Uri Huppert, PhD - a lawyer, Jerusalem; he is a retired lecturer at the Cleveland State University and the Kozminski University. 


\section{Jerozolima w potrzasku między Watykanem, Moskwą, ewangelikami republikańskimi, mesjanizmem judaistycznym i islamem}

\section{Streszczenie}

Jerozolima, a szczególnie Góra Świątynna (Moria), została uświęcona przez trzy największe monoteistyczne religie. Przez judaizm - przez poświęcenie Izaaka (Stary Testament), ustanowienie Jerozolimy przez króla Dawida stolicą starożytnego państwa Izraelitów i dwie zburzone świątynie. Przez chrześcijaństwo - Chrystus modlił się w Drugiej Świątyni, został w Jerozolimie ukrzyżowany i pochowany. Na tejże Górze Świątynnej, na gruzach Drugiej Świątyni, posadowiono meczet muzułmański Al Aksa.

Współczesny konflikt wyznaczony został przez: powstanie Państwa Izraela (1948) i opanowanie wschodniej Jerozolimy (1967), wpływy Moskwy poprzez prawosławie i kościoły orientalne, wpływ polityczny mesjanizmu żydowskiego przy masowym wsparciu fundamentalizmu ewangelickiego poprzez partię republikańską w Stanach Zjednoczonych, konflikt islamu z Zachodem i Izraelem, skoncentrowany wokół Jerozolimy jako punkt zapalny „współczesnych Mesjaszów”.

Słowa kluczowe: fundamentalizm, Jerozolima, konflikt, Bliski Wschód 


\section{Introduction}

In 1983, 36 years ago, an American newsmagazine devoted to political science, "Executive Intelligence Review", passed an ominous prognosis: "Temple Mount fundamentalists launching new Mideast holy wars".

The provocative catchphrase passed by the American review of political science was, undoubtedly, based on two hard facts: in 1967, Israel dominated the entire territory by the River Jordan and incorporated whole Jerusalem, including the Temple Mount. A right-wing group, later known as the Moral Majority, was already forming in the United States in the 1970s in order to stop the waves of liberal organisations acting under the motto of equality and the rights of individuals.

\section{Jerusalem between Denominations}

The purpose of this paper is to present this issue and the conflict with the Church of Rome (Catholic Church) and the Oriental Orthodox Churches, represented by Moscow Orthodoxy. The Muslim world became involved in this conflict. Judaism, represented by Israel's military power, very brilliantly shown in the Six-Day War which was worked out very well in terms of strategy.

Every tourist will easily confirm the centuries-old and physical presence of Eastern Orthodox churches in Jerusalem, particularly Russian ones, financially supported by the Moscow government - not only by the Tzar, and even the government acting under the umbrella of the Soviet Union, and nowadays under the umbrella of Putin's Russia (known then as "the Red Church"). In the heart of Jerusalem, the great church reigns over the so-called "Russian district" (Russian Compound) and confirms Moscow's bond with Jerusalem.

A new Christian denomination which was born in North America has a political - and more and more visible day by day - influence on the policy of Israel, Palestine and Jerusalem. This is a conservative, fundamentalist evangelist movement with anti-liberal inclinations. 


\section{Jerusalem - the Near East}

As I have mentioned, the framework of this paper is limited to the issue of Jerusalem. However, it is difficult to isolate this problem from the fact that Jerusalem is located on the continent of the Near East.

Conceptually, it is also impossible to isolate mainstream Zionism from the secular vision of the state of Israel, which I hereby note.

I would like to emphasise, in the framework of this paper, that the original concept deliberately separated the secular-national element from the connection of religion to orthodox Judaism. Political Zionism did not associate the Jewish religion with national origin (this topic is known in judgements of the Supreme Court in Jerusalem, and in literature devoted to political science - I referred to the issue in several Polish publications, including a study published as a book. ${ }^{2}$

\section{Jerusalem in the National Context}

Trying to take care of the limited framework of this paper, I feel, however, obliged to mention, incidentally, a new work by Jerusalem historian, Dr Dmitry Shumsky. It is entitled Beyond the National State. ${ }^{3}$

Dr Shumsky intrigues the reader with several fundamental questions: was the purpose of Zionism the creation of a national state? Did the sovereignty of the Jewish nation in the biblical cradle not envisage a multinational concept? Was Jewish national autonomy not devised as a separate circle of the then Ottoman Empire or perhaps the then I.R. Austro-Hungarian Empire or the Polish-Lithuanian Commonwealth?

Dr Shumsky's questions are particularly relevant, both in reference to the American evangelical vision, forcefully put into practice by the United States in relation to Jerusalem, and in reference to the "Act on Nation" which was recently forced through by Prime Minister Netanyahu. This act exacerbates the conflict with national minorities, and the exposure of a religious identification affects relations with Islam. Muslims demand that the caliphate be restored. It is naturally supposed to cover Jerusalem as the Muslim holy city Al-Quds.

In this paper, I will attempt to present a viewpoint that evangelists - in the name of the national interest of conservative America as they understand it - freely use Jewish messianists in order to, on the way to establishing "Christ's second

2 U. Huppert, Izrael w cieniu fundamentalizmów, Torun 2016.

3 D. Shumsky, Beyond the National State, New Haven, CT 2019. 
coming" in Jerusalem, on the Temple Mount, lead to an inferno with the Muslim world and with Moscow.

\section{Evangelists and Politicised Theology}

In the 1970s, miniature anti-Catholic churches formed a union under the name "Moral Majority".

This community, which then amounted to 45 million members, currently - in the 21st century - has an estimated number of 65 million members in the United States and millions of members in Brazil and Scandinavia. Nowadays, evangelists, as conservatives, dominate in the Republican Party and sets the tone for the policy in the Near East and Israel thanks to the messianic-orthodox right which nearly half of the Israeli electorate complied with.

There was an evident confrontation of three religions in Jerusalem:

$\square$ religious Judaism, theologically and politically divided between orthodoxy, conservatism and reform liberalism, which constitutes the vast majority of American Jews.

Western and Eastern Christianity, with a strong Orthodox Church factor remaining under the political influence of Moscow.

- Sunni Islam under the umbrella of Saudi and Jordan, and Shiite Islam, led by Iran.

Orthodox Judaism ethnocentrically considers itself the nation which owns religion. The traditional doctrine of Islam believes, similarly to Judaism, that a nation is based on the common Muslim religious bond.

The association with Jerusalem becomes complicated in reference to two significant branches of Christianity: the Moscow Orthodox Church considers itself to be the heir of the Byzantine Church and, thus, the guardian of holy places of the Near East, especially Jerusalem.

\section{The Nationalisation of the Near East}

Nowadays, three dramatic events shook the Near East which was under the umbrella of the Turkish, Muslim (Sunni) Ottoman Empire.

After the end of the First World War, and earlier in 1916, three then-empires planned to make a dramatic division of the Turkish state and the Near East. Tzarist Russia, France and Great Britain were supposed to be the signatories of the new 
order. The revolution of secular Bolshevism and the fall of Tzarist Russia left only Great Britain and France at the meeting table. The ambitions of Moscow were not consummated at this stage.

Finally in 1916, the agreement on the division of the Near East was realised. The treaty, which bore the names of its signatories, Sykes-Picot, became a fact, ${ }^{4}$ and so, "national" Arab states: Transjordan, Iraq, Syria, Lebanon, and Palestine were established on tribal ruins (from the Mediterranean Sea to the River Jordan in the east). Palestine, under the umbrella of the League of Nations, was de facto subordinate to Great Britain as a "mandate", so it was not a colony of the United Kingdom.

It was decided that Jerusalem would be the capital of the mandate. This way, the biblical tradition, going back to King David's Israeli capital from three thousand years ago and to the Teutonic medieval "kingdom of Jerusalem", which was recovered from Muslims for nearly two hundred years, was returned. This order, drawn by France and Great Britain, survived for about one hundred years.

\section{National Homes for the Disabled}

The Second World War significantly weakened France and Great Britain. Despite the Allies' victories, but not less due to the Enlightenment which strengthened the rights of the individual and the right to national self-determination (which developed in the 19th century), fertile ground for the liberation movement of American slaves was provided.

In 1847, independent Liberia was created in western Africa, and in 1808, the crown colony, Sierra Leone (independent since 1961), was created as the new homeland of British slaves.

Even Joseph Stalin joined the leaders who initiated the solving of the problem of "eastern" Jews (ostjuden), the victims of massacres. Stalin thought that a nation is characterised by presence on a specific territory.

As stated by Artur Patek, PhD, "during the Tzar's reign, the fate (of Jews) was dominated by repression, discrimination and massacres." ${ }^{5}$ Masses of the eastern Jews, less educated in comparison with the emancipated Jews of the West, allegedly received their national solution in the "Jewish Autonomous Oblast" in the Soviet Union, together with Chinese, Korean and Slavic locals.

See M. Górny, Kreślarze ojczyzn, Warszawa 2018.

5 A. Patek, Birobidżan. Sowiecka ziemia obiecana, Kraków 1997. 


\section{Israel - a New Reality}

Concurrently, James Balfour, the Minister of Foreign Affairs of Great Britain, passed a catchphrase "Home for Jewish People in Palestine" in 1916. However, perhaps he envisioned the emancipated Jews of West.

And so, on 29 November 1947, the General Assembly of the UN allowed the formation of a state for Jews on a part of the territory of Mandatory Palestine. In response, the neighbouring Arab states (Egypt, Transjordan, Iraq, Lebanon, Syria) attacked the embryo of the new state. The newborn State of Israel pushed the aggressors away, and it was proclaimed in May 1948.

As the result of the war, called a "liberation war", Western Jerusalem remained on the Israeli side. Eastern Jerusalem, including the Old City and the Temple Mount - Moriah - became a part of the Hashemite Kingdom of Jordan. It is worth noting that the Arab League, despite capturing the Old City of Jerusalem, retained its capital in Amman.

The division of Jerusalem was eliminated as the result of the Six-Day War, and on 30 June 1980, the Israeli parliament (the Knesset), in the light of the Basic Law (Journal of Laws of Israel No. 980 of 5 August 1980), incorporated Jerusalem (extended by small towns which had not been within "mandatory" Jerusalem before), establishing it as the capital of the State of Israel.

The Act of the Knesset, however, collided with the decision on the division of Palestine of 29 November 1947. The Resolution No. 181 of the General Assembly of the UN states that Jerusalem shall constitute a "free city" within the municipal limits of the "mandate". The Vatican considers this decision binding to this day.

\section{The Vatican, Israel in the Times of John Paul II}

In this context, Pope John Paul II's official visit to Jerusalem was worthy of particular attention. Not only did he make a pilgrimage to the Holy Land, but he ostentatiously visited Yad Vashem on 22 March 2000, meeting former residents of Wadowice - his friends from school - as well as officially meeting the President of Israel in his residence in Jerusalem. He also met Prime Minister Ehud Barak. The Pope also left a symbolic card by the Wailing Wall, the reminiscence of the Second Temple, ruined by Roman Titus. It was, undoubtedly, a political act.

On 26 October 1994, the king of Jordan, Hussein, and the Prime Minister of Israel, Yitzhak Rabin, decided together that Jordan would give up on its rights to Mandatory Palestine, and Israel - under Article 9 of the Peace Treaty - would recognise the special position of Muslim holy places in Jerusalem. The above-mentioned 
Article ends with the following declaration: "The Parties will act together to promote interfaith relations among the three monotheistic religions, with the aim of working towards religious understanding, moral commitment, freedom of religious worship, and tolerance and peace".

Thanks to the treaty, King Hussein - as Muhammad's descendant - retained the position of the Muslim world, also on the part of the new sovereign of Jerusalem, in the name of Sunni Islam. The State of Israel de facto became that sovereign.

\section{Evangelists as neo-Zionists}

In 1981, the Prime Minister of Israel, Menachem Begin, met the leader of the Moral Majority, pastor Jerry Falwell. The then-anonymous young diplomat - Benjamin Netanyahu - participated in the meeting.

It was here where a great and very significant love affair between Jewish messianists and the Israeli right and the influential organisation of evangelical Christians, managing the Near-Eastern policy of the Republican Party on the Capitol in Washington and in the White House (by Republican presidents, such as Ronald Reagan, both Bushes and Donald Trump), began.

At this point of the discourse, three thousand years of the history of the holy city - Jerusalem - should be presented very briefly.

Three thousand years of the history of Jerusalem are presented by the Bible. The Book of Genesis describes the drama of sacrificing Isaac on Mount Moriah which is contemporarily known as the Temple Mount (Genesis, 22, 1-2). Isaac's would-be sacrifice is also mentioned in the New Testament (Hebrews, 11, 17-19).

King David, the ruler and symbol of the united Israeli kingdom, pronounced Jerusalem the capital and ruled it from 1040 BC (he supposedly died in 970 BC). The tradition says that he was buried on Mount Zion in Jerusalem. That is also where Christ reportedly had the Last Supper. This hill of Jerusalem was also a symbol of the national Zionist movement.

The special, divine origin of Jerusalem is also related to Christ who was born in Bethlehem. As described in the New Testament, Christ prayed in the Jerusalem temple on the Temple Mount - Moriah, and later - in Jerusalem - he was crucified. Christ's tomb is in this Jerusalem - in the heart of the Old City, in the Christian district.

However, this monotheistic duo of Judeo-Christianity was dramatically violated in the 7th century. 


\section{Muslims Conquer the Near East}

Over one thousand, five hundred years of the rivalry of Christianity and Judaism, despite their common core, showed the unprecedented clout of two versions of Christianity - the Western one, as well as the Eastern one.

Christianity is the biggest monotheistic religion in the world to this day. In the New Testament (the Gospels of Matthew, Mark, and Luke), Judas Iscariot was accused as a traitor who gave Christ up to Roman torturers.

Generations of Christians accused Jews of originating from Judas, and repression against the Jews was supposedly meant to commemorate that betrayal. The Jews were supposed to pay with their blood for the alleged betrayal to the end of all generations.

The Judeo-Christian "monopoly" on monotheism was, however, undermined. A new prophet of monotheism, Muhammad (who lived most probably between 570-632 AD), stepped onto the arena of world religions with a great impetus. The new prophet of monotheism promoted fighting with weapons for religious dominance in the world.

According to the tradition which is binding for Muslims, by the will of God (Allah), Muhammad wrote the Great Manifesto, known as the Quran. The Quran, as the holy book of Islam, mentions only two centres of worship: Mecca and Medina.

Jerusalem, as a holy city (Al-Quds), is only the creation of a tradition which describes that prophet Muhammad reportedly flew up to heaven on his courser called Buraq, springing up from the Temple Mount. The hoof-print of the holy horse can supposedly be seen by its worshippers. Here, on the ruins of the Second Temple, the Muslims built the Al-Aqsa Mosque, and so the Judeo-Christian conflict transformed into a conflict with the Muslims whose number amounts to 1.8 billion today.

The Vatican as a political factor of the West was out of the picture of the Near East (but it still partially supported the independent status of Jerusalem), and the initiative was taken by Moscow Orthodoxy. The European West acted in the name of its civilisation (Great Britain, France), but without promoting any religious option.

\section{Over 60 Contradictory Proposals for Resolving the Jerusalem Conflict}

The above-mentioned article from the American newsmagazine from 1983 and a recently published article in "The Economist" (March 2019) warn Israel and the Near East of a catastrophe. 
The year 1967 introduced into the political arena the renewal of the player: messianism in the territorial and political context.

Rev. Stanisław Łach writes: "Messianism, next to monotheism, is one of the central ideas of the whole Bible. It exists in books of the Old Testament in the form of a promise, which is preached again and again, that Yahweh will send to Israel and all humankind a Saviour, called the Messiah, who will be the one to remove all injustice and wars from earth, and will start the Kingdom of Heaven on earth which will be full of happiness and peace. In books of the New Testament, in turn, messianism appears as the fulfilment of the promise, as Christ of Nazareth is presented here as the foretold Messiah." ${ }^{16}$ Rev. Łach continues, referring to more modern theories: "Messianism was reportedly created by later prophets who started to have various speculations about the future after monotheism was established. However, these speculations were rather political in nature. It was only the national failures of the Israelites, the fall of their state, taking them captive into slavery that became the direct source of messianism with its visions of restoring Israel and its eternal kingdom of the Son of Man, which would follow the humiliation of Israel and the Davidic dynasty, presented in the image of the Servant of God."

The Six-Day War was a particularly successful escapade of the secular government under the rule of Prime Minister Levi Eshkol, his Minister of Defence, Gen. Moshe Dayan, and Chief of Staff - the future socialist Prime Minister - Yitzhak Rabin.

David Ben-Gurion declared in an interview for "Haaretz", as he referred to the territorial successes of Israel: "I opt for the creation of the Palestinian state outside Jerusalem and its surroundings", and he added: "I caution against occupying another nation and against thereto related repression."

The so-called "Jerusalem Institute" which functions in Jerusalem, issued a detailed list of 62 proposals for resolving the religious and political conflict (The Jerusalem Institute for Israel Studies, The Hay Elyachar House, 1994). I will quote only several ones:

$\square$ the previously mentioned Sykes-Picot treaty proposes international sovereignty for Palestine, including Jerusalem (in the end, Great Britain received the mandate from the League of Nations, becoming formally a trustee of, and de facto - the ruler of Palestine)

$\square$ the mandate card (1922) gave responsibility for Jerusalem back to Great Britain

$\square$ by the Resolution No. 181, the General Assembly of the UN expressed an opinion that Jerusalem should become a corpus separatum internationally

6 S. Łach, Geneza mesjanizmu biblijnego, „Ruch Biblijny i Liturgiczny” 1970, 4-5, p. 167. 
$\square$ in the proposal of Israel of 26 May 1950 (at the time of Jerusalem's division between Israel and Jordan), the UN was made responsible for places of worship in Jerusalem

$\square$ the Jerusalem vice-mayor's proposal from 2 July 1968: 1) to open the whole municipal circuits governed by Israel; 2) to divide Jerusalem into independent municipalities according to the nature of the residents, including Bethlehem

- Saudi Prince Fahd's peace plan from 3 August 1982: 1) Israel will withdraw from the occupied Palestinian territories and from western Jerusalem which will become the capital of the Arab state of Palestine; 2) the UN will be responsible for places of worship in Jerusalem

the joint plan of Nusseibeh, PhD (Palestine) and Heller, PhD (Israel), from 1991: 1) the division of Jerusalem into the eastern (Arab) part and the western (Israeli) one with open passages; 2 ) the common capital; 3) holy places governed by each of the religions.

\section{Old Messiahs in New Clothes Play Out the Temple Mount}

I think that it is hard to doubt the electrifying power of the Six-Day War (1967), the fever of Islamic terrorism and the new Christian player on the arena of the world politics. These new (or renewed) powers are unquestionably a modern phenomenon. Raymond Aron, a great French political scientist, firmly said that the fall of totalitarian - red, brown and black - regimes opens the world for an era of humanism and liberalism.

Journalist Akiva Eldar and historian Idith Zeldar published in 2005, in Hebrew, a book entitled Lords of the Land and treated it as the knife aimed at the messianic Jewish colonisation, usurping the rights to the part of Palestine inhabited by the Arabs. ${ }^{7}$ The book's motto is a quotation from the son of former Chief Rabbi Zvi Yehuda Kook. In a free translation, it goes: "Lord has a specific policy here on earth (...) part of the beginnings of the Messiah's second coming is announced with recovering this land again, and no secular politics will measure up to (this work)." The authors gave a significant title to one of the chapters, The Pace of Apocalypse, providing statistical data on victims (in thousands) on both sides of the "barricade".

7 A. Eldar, I. Zeldar, Lords of the Land: The War for Israel's Settlements in the Occupied Territories, 1967-2007, Dvir Publishing House 2005. 
Generated Jewish messianism and anti-liberal, conservative evangelical neomessianism were not foreseen by Raymond Aron.

In 1979, I wrote in my book: "The Nationalistic camp, strongly influenced by messianic-fundamentalistic religious-Orthodoxy, pays lip service to Jabotinsky, using him as a leading common denominator of the Israeli Right. It is only natural that the Right should express emotional and political understanding toward Orthodox religious demands while having no moral nor political obligations toward the non-orthodox, mainly liberal, and even anticlerical Jews in America, who are so sensitive to universal issues of freedom and equality and who are frequently critical of Israeli domestic and international affairs. The newly born Israeli right-wing establishment is developing good relations with the American Orthodox minority. This American orthodoxy is expressing its growing appreciation to the American right win as well."

The publications, including my observations, were only a humble aftermath of authentic events which tragically wound around Jerusalem.

In August 1969, Australian Christian, Denis Michael Rohan, was stopped by the Israeli police during an attempt to set the Al-Aqsa Mosque in Jerusalem on fire. The offender was declared insane in the sentence, and was extradited to Australia.

The same year, the Israeli Ministry of Religious Services, under the umbrella of the national-religious minister, Dr Yosef Burg, undermined the Temple Mount, against the government's directives.

However, let us move on to 1973. Nathan Lerner-a Jew, member of the "League" of Rabbi Kahane, emigrant from the United States, alumnus of the prestigious MIT - began a canvassing action by means of leaflets: "The culture of Israel is unable to co-exist with the civilisation of the West (...) human activities are pointless unless they fulfil the will of God (...)."

Lerner engaged in dialogue with me and argued that parliamentary legislation is unworthy because one should only act under the rigour of the higher, divine rank.

\section{Judas Iscariot}

Nowadays, the political situations in Israel on the eve of parliamentary elections, as well as in the United States, are based on the Republican Senate of Donald Trump, and above all - on the growing support for the evangelical movement.

$8 \quad$ U. Huppert, Back to the Ghetto, Amherst, NY 1979. 
The movement of traditional Lutherans and a whole array of non-Catholic Christians, including Baptists and Pentecostals, has had an ambivalent attitude towards the historical role of Judas Iscariot, and particularly towards the crime of betraying Christ, which is attributed to Judas, for years. Evangelical fundamentalists rejected the betrayal version, which made it easier for them to co-operate politically with Israeli Jews, especially with the Israeli right and anti-secular messianism.

A dramatic archaeological discovery in Egypt, spread by the prestigious monthly magazine "National Geographic" (April 2006) gave an additional impetus to the co-operation with Israeli national-religious and right-wing politicians. Archaeologists discovered a Christian text in Coptic, regarded as the Gospel of Judas, not included in the New Testament.

This Gospel presents a version, according to which Judas performed the act of pointing out Christ upon request from Christ himself, in order to fulfil the latter's will of being crucified. The document confirmed the alliance of the messianic evangelists with the Israeli right whose goal is to incorporate Arabic (occupied) Palestine and unconditionally confirm Jerusalem as the sovereign and indivisible capital of Israel. All of this against dozens of academic and political proposals and decisions legitimised by the UN.

\section{Evangelists' New Crusade}

The goal of evangelical theologists is naturally completely different from the secular business of the State of Israel. It is also contradictory to the Jewish messianists' theology. One does not talk about this, but it is, however, worth mentioning how important today's political acts are.

The decision of the United States about pronouncing Jerusalem the capital of Israel echoed negatively among the Palestinians as well as in the Catholic world and Moscow and Eastern Orthodox Churches. Objective observers are afraid that this is not the way to resolve the religious and political conflict.

David Smith, a commentator for the British liberal journal "The Guardian" in Washington, writes in the report from Tuesday 15 May 2018: "It was a historic and bloody day for Israel (...) The selections of pastors Robert Jeffress and John Hagee was a sign of how for some Christians the recognition of Jerusalem as Israel's capital in consistent with the biblical prophecy of the second coming of Jesus Christ (...)" and then: "(...) it was also illustrative of how central the evangelical constituency has become to Donald Trump's support", and referring to the Israeli scene, he writes: "it was an important show of solidarity with the hardline Israeli prime minister, Benjamin Netanyahu”. 
Moscow, which has been fighting for dominance in the Near East for centuries, has its bases in Syria again, and Israel is threatening its neighbours and threatens the Muslims with its messianic aspirations.

A dramatic historical analogy, or rather a sarcastic frolic which seemed unimaginable until recently, imposes itself on one.

The Crusaders, going from Christian Europe to the Near East to free the Holy Land and Jerusalem from the Saracens ("godless" Muslims) practised their knightly skills by mass murders and massacres committed on European "descendants of Judas". These massacres were a prelude to the Spanish Inquisition and the German Holocaust.

Nowadays, paradoxically, the right-wing Prime Minister of Israel, who is supported by the local messianists, stands together with the pastors of Christian evangelists in the war against Muslim natives.

That messianist Israeli right transformed, how unnecessarily, a solvable national conflict into a religious war in which the contemporary government in Israel fraternised with the neo-Christian evangelists, which means that it rejected the secular concept of the founders of Israel.

The founders of the Jewish national movement were aware of the fact that only the Knesset - the secular parliament - and not the Temple Mount, is to be the realisation of the announcement of the nation's return to its biblical homeland.

Moscow, cunningly associated with Iran (the Shiites) as well as with certain Arab (Sunni) states and supported by the Eastern Orthodoxy by Eastern Orthodox churches is becoming a factor that will leave its mark in the Near East.

I am afraid that these conflicts will, nolens volens, be focused on Jerusalem.

A historical paradox of the politics of the messianists' coalition is conspicuous. Nowadays, the new evangelical Christians lead their crusade with the hands of the Israeli leader who has the function of the "Grand Master of the Evangelical Order".

One day before submitting this paper for print, the dramatic weakening of the United States' position in Syria strengthens Putin's Moscow and foreshadows Russia's intervention in the Palestinian-Israeli conflict and in the position of Jerusalem to the detriment of the evangelists and the Jewish messianists, and it threatens with the political fall of Prime Minister Benjamin Netanyahu who is associated with the American Christian right.

\section{Bibliography}

Eldar A., Zeldar I., Lords of the Land: The War for Israel's Settlements in the Occupied Territories, 1967-2007, Dvir Publishing House, Israel, 2005.

Górny M., Kreślarze ojczyzn, Warszawa 2018. 
Huppert U., Back to the Ghetto, Amherst, NY 1979.

Huppert U., Izrael w cieniu fundamentalizmów, Torun 2016.

Łach S., Geneza mesjanizmu biblijnego, „Ruch Biblijny i Liturgiczny” 1970, 4-5.

Patek A., Birobidżan. Sowiecka ziemia obiecana, Kraków 1997.

Shumsky D., Beyond the National State, New Haven, CT 2019. 